Tokgöz, E. / Journal of Yasar University, 2020, 15/59, 584-597

\title{
Dış Görünümde Markalı Ürün Kullanma Bilincinin Gösterişçi Tüketim Üzerine Etkisi: Marka Duygusu ve Cinsiyetin Düzenleyici Rolü
}

\author{
Impact of Face Consciousness on Conspicuous Consumption: The Moderating \\ Role of Brand Affect and Gender
}

\author{
Emrah TOKGÖZ, Çanakkale Onsekiz Mart Üniversitesi, Türkiye, emrahtokgoz@ yahoo.com \\ Orcid No:0000-0003-3761-9934
}

\begin{abstract}
Öz: Dış görünüş, bir kişinin sosyal etkileşim sürecinde sahip olduğu olumlu imajı temsil eder. Dış görünümde markalı ürün kullanma bilinci yüksek olan kişiler gösterişçi tüketim yapabilir. Bu davranışsal etkinin altında yatan temel neden marka duygusu olabilir. Çünkü marka duygusu, tüketici ve marka arasındaki ilişkiyi açıklamaya yardımcı olan kavram olarak kabul edilir. Diğer taraftan marka duygusu cinsiyet açısından farklılık gösterebilir. Buradan hareketle araștırmanın amacı, dıs görünümde markalı ürün kullanma bilincinin gösterișçi tüketim üzerindeki etkisinde, marka duygusunun ve cinsiyetin düzenleyici rolünün belirlenmesidir. Araştırmada, dağıt topla yöntemiyle, kullanılabilir durumda 454 anket uygulanmıştır. SPSS programına yüklenerek kullanılan PROCESS Makro yazılımı, düzenleyici analizi yapılmasına yardımcı olmuştur. Sonuçlara göre dış görünümde markalı ürün kullanma bilincinin gösterişçi tüketim üzerindeki etkisi marka duygusu yüksek olan tüketicilerde daha fazla etkilidir. Bu etkinin, marka duygusu yüksek olan erkek tüketicilerde daha güçlü olduğu anlaşılmıştır. Sonuç bölümünde teorik tartışmanın ardından, pazarlama yöneticilerine markalı ürün pazarında uygulayabilecekleri potansiyel pazarlama stratejileri önerildi.
\end{abstract}

Anahtar Sözcükler: Dıș Görünümde Markalı Ürün Kullanma Bilinci, Gösterișçi Tüketim, Marka Duygusu, PROCESS Makro Model JEL Siniflandırmasi: M30, M31, M39

\begin{abstract}
Face represents an individual's claimed sense of positive image in the process of social interaction. Consumers with a high level of face consciousness may consume conspicuous using branded products. The main reason underlying this behavioral effect is defined as brand affect. Because brand affect is considered as a concept that helps explain the relationship between consumer and the brand. On the other hand, the force of brand affect may differ in terms of gender. From this point of view, the aim of the study is to reveal the moderating role of brand affect and gender in the relationship between face consciousness and conspicuous consumption. In the study, 454 usable completed questionnaires were received by using self-completion survey method. PROCESS Macro software, which was used by installing SPSS program, helped to perform moderating analysis. According to the results, it is revealed that the effect of face consciousness on the conspicuous consumption is more effective for consumers with high brand affect. This effect is more powerful for men with high brand affect. In the conclusion section, after theoretical discussions, marketing managers were advised potential marketing strategies that they could apply in the branded product market.
\end{abstract}

Keywords: Face Consciousness, Conspicuous Consumption, Brand Affect, PROCESS Macro Model JEL Classification: M30, M31, M39

\section{Giriș}

Son yıllarda ülkemiz literatüründe gösterişçi tüketim kavramının materyalizmle ilişkilendirilen farklı konular yardımıyla açıklanmaya çalışıldığı görülmektedir (Balıkçıoğlu ve Volkan, 2016; Bayuk ve Öz, 2018; Dal vd., 2018; Becan ve Eaghanıskouı, 2019; Tokmak, 2019). Ancak Türkiye gibi toplumsal kültüre yakın tüketicilerin gösterişçi tüketim yapma nedenlerini sadece batı stili materyalizmle ilişkili olan kavramlar yardımıyla açıklamak yeterli olmayabilir. Çünkü bireyci ve toplumsal kültüre yakın tüketiciler, aynı ürünü farklı nedenlerle satın alıyor olabilir (Li ve Su, 2007: 238; Vohra, 2016: 59; Li vd., 2018: 621). Söz konusu tüketim farklılığını ortaya çıkaran nedenlerden birisinin, toplumsal kültüre yakın tüketicilerin davranışlarını etkileyen "dış görünüm bilinci" (face consciousness) olarak ifade edilen bir kavram olduğu ileri sürülmektedir (Oetzel ve Ting-Toomey, 2003: 600). D1ş görünüm bilinci, insanların sosyal karşılaşmalarda kendilerini olumlu bir şekilde tanıtmak için dış görünüşlerini yönetme arzusudur. Dolayısıyla dış görünümde markalı ürün kullanma bilinci yüksek tüketiciler, toplum önüne çıkarken tükettikleri mal ve hizmetler konusunda dikkatli olduklarından, markalı ürünleri sembolik bir sosyal başarı olarak kullanmak için satın alabilirler (Lee vd., 2017: 1). Bu konuda dünya literatüründe oldukça az sayıda araştırma yapıldığı (Zhang ve Wang, 2019), ülkemizde ise henüz çalışılmamış bir konu olduğu görülmektedir. Bu nedenle araştırmanın temel sorusu, dış görünümde markalı ürün kullanma bilincinin gösteriş̧̧i tüketim üzerinde etkisi var mıdır? olarak belirlenmiştir.

Tüketiciler, markalı ürünün kullanımı sonucu olumlu bir duygusal tepki verebilirler. Buna göre tüketici, markalı ürün kullanım sırasında ve sonrasında mutlu, iyi ve keyifli duygular hissedebilir. Matzler ve diğerleri (2006: 427) bu duyguları, markalı ürün kullanımına karşı hazcı tutum olarak da tanımlamaktadır. Bu durumda marka duygusu, doğası gereği,

Makale Gecmiși / Article History

Başvuru Tarihi / Date of Application

: 14 Aralık / December 2019

Kabul Tarihi / Acceptance Date

: 27 Ocak / January 2020

(C) 2020 Journal of Yaşar University. Published by Yaşar University. Journal of Yaşar University is an open access journal.

There is no conflict of interest or ethical concern regarding this publication. 
tüketici ile marka arasında psikolojik bir ek olarak tanımlanmaktadır. Başka bir ifadeyle, tüketicinin markaya karşı tutumu bilişsel değil duygusal olabilir. Söz konusu duygusal tutumun duyusal deneyim yaşandığında ortaya çıkma ihtimali daha yüksektir (Dick ve Basu, 1994: 104). Dolayısıyla tüketicinin markaya karşı olumlu duygusal birikimi yükseldikçe dış görünümde markalı ürün kullanma bilinci de yükselişe geçecektir ve sonuç olarak tüketici gösterişçi tüketim yapacaktır. Çünkü dış görünümlerine önem verenler, satın aldıkları ürünlerin üzerinde markayı tanımlamayı sağlayan, görünür bir logosu olan ürünleri tercih ederler. Bu tür kişiler, ürünlerin iç niteliklerinden ziyade diş niteliklerine daha fazla dikkat etmeleri nedeniyle gösterişli tüketim yapabilirler (Chen vd. 2014: 1008). Buradan hareketle araştırmanın ikinci sorusu, dış görünümde markalı ürün kullanma bilincinin gösterişçi tüketim üzerindeki etkisi, marka duygusu yüksek olan tüketicilerde daha fazla mıdır? olarak belirlenmiştir.

Tüketiciler karar verirken hem duygularından hem de bilincinden yararlanırlar. Başka bir ifadeyle, tüketici marka hakkında az bilgi sahibi olduğu zaman duyguların karar verme süreçlerini etkilediği, marka hakkında bilgi sahibi olduklarında ise bilincin karar verme süreçlerini etkilediği söylenebilir. Markalı ürün satın alırken duygu ve bilinç kullanım derecesi cinsiyetler açısından farklı olabilir (Melnyk vd., 2009: 82). Ayrıca kadınlar ve erkekler sosyal çevrelerinde de farklı davranırlar. Kadınlar daha çok kendi kendine odaklanan bireyci kültüre yakın, erkekler ise grup kimliğine önem veren toplumsal kültüre yakın duygulara sahiptir. Dolayısıyla, tüketicilerin marka duygusu cinsiyet açısından farklılık gösterebilir (Sahay vd., 2012: 37). Bu durumda araştırmanın üçüncü sorusu, dış görünümde markalı ürün kullanma bilincinin gösterişçi tüketim üzerindeki etkisi, kadın ve erkek tüketicilerin marka duygusu seviyesi açısından farklılık göstermekte midir? Buradan hareketle araştırmanın amacı, dış görünümde markalı ürün kullanma bilincinin gösterişçi tüketim üzerindeki etkisinde, marka duygusunun ve cinsiyetin düzenleyici rolünün belirlenmesidir. Araştırma amacına ulaşabilmek için Hayes (2013) tarafindan oluşturulan (www.processmacro.org) ve daha sonra geliştirdiği (Hayes, 2018), SPSS programına yüklenen PROCESS Makro yazılımı kullanılmıştır.

\section{Kavramsal Çerçeve}

\subsection{Tüketicinin Dıș Görünümde Markalı Ürün Kullanma Bilinci}

İngilizce literatürde "yüz bilinci” (face consciousness) olarak ifade edilen ve bireyin sosyal etkileşim bağlamında sahip olduğu iddia edilen olumlu imaj duygusunu temsil eden kavram (Oetzel ve Ting-Toomey, 2003: 600), Türkçeye “dış görünüm bilinci” olarak çevrilmektedir. Dış görünüm kavramı, bir kişinin toplum içinde olumlu bir sosyal benlik duygusu yaratmak adına, diğerlerinin kendisinden sahip olmasını istediğini düşündüğü genel duruş olarak tanımlanabilir (Chen vd., 2018: 3). Dolayısıyla dış görünüm bilinci, sosyal beklentileri ve grup üyeliğini ön plana çıkarmaktadır (Grainger vd., 2010: 2159). Bu durum, tüketicinin markalı ürün kullanma davranışlarında da görülebilir. Tüketici, satın aldığı markalı ürünleri diğer insanlara karşı kullanabileceği bir tür sosyal çağrışım aracı olarak düşünebilir. Dolayısıyla tüketici dış görünümünü güçlendirdiği düşüncesiyle bilinçli olarak markalı ürün kullanabilir (Bao vd., 2003: 736).

Bazı tüketiciler, başkaları tarafından nasıl algılandıklarına ve sosyal statü derecelerinin diğerleri tarafından nasıl değerlendirildiğini önemser. Yüksek dış görünüm bilincine sahip tüketiciler, ne kadar zengin ya da fakir olduklarına bakılmaksızın, halka açık ortamlarda markalı ürünlerin tüketimine önem verirler. Çünkü bu tür davranışlar onlar için kişilerarası iletişim aracı olarak değerlendirilir (Liao ve Wang, 2009: 991). Genel olarak, dış görünüm bilincine ilişkin tüketim yapmanın üç önemli özelliği olabileceğini ileri sürülmektedir: Birincisi, satın alınan ürün markalı olmalı. İkincisi, satın alınan ürünün sosyal bir anlamı olmalı. Üçüncüsü, dış görünüşüne önem veren tüketici, diğer insanların da dış görünüşünde markalı ürün kullandığına dikkat etmeli (Li ve Su, 2007: 242). Markalı ürün kullanma bilinci, tüketicinin dış görünüşünü korumanın ve güçlendirmenin önemli bir yolu olduğundan, çeşitli tüketici davranışlarını açıklamada kullanılan önemli bir değişkendir (Li vd., 2015: 2). D1ş görünüm bilinci kavramı özellikle doğu kültürünü anlamak için yapılan araştırmalarda sosyal yaşamı düzenleyen temel bir ilke olarak düşünülmektedir (Zhang ve Wang, 2019: 5).

Dış görünüm bilinci, tüketicinin sosyal eylemlerinde dış görünümünü korumak veya iyileştirmek istediğini ortaya koymaktadır (Aziz ve Habib, 2017: 62). Toplum içinde yaşayan birer sosyal varlık olarak hepimizin yüzü kızarmış, utanmış, mahcup olmuş veya sakarlık yaptığımız zamanlar olmuştur. Böyle zor durumlara düşmemek için insanlar sosyal duruşlarının zayıf olabileceğini düşünerek dış görünümlerini korumaya çalışırlar (Belk, 1988: 152). Toplum içinde dış görünüm bilinci, bir bakıma, ahlaki karakterin bütünlüğüne olan güveni temsil etmektedir; bunun kaybı, toplum içinde düzgün şekilde iletişim kurmayı da imkânsız kılabilir (Gao, 1998: 468). Bir bakış açısına göre dış görünüm insanlar için sosyal benlik oluşturma yolu olduğundan, toplumsal kültürlerde bireylerin dış görünümlerini olumlu yapma endişesi daha baskın hissedilebilir. Bu tür toplumsal kültürlerde, bireylerin dış görünümlerinden yansıyan saygınlık sadece kendi benliklerini oluşturmada değil ait oldukları aile, arkadaşlar veya meslektaşlar gibi toplumsal ilişkilerine de dayanmaktadır. Bu nedenle güçlü bir dış görünüm algısına sahip olan kişiler bu konuda güçlü bir bilince de sahiptir (Wong ve Ahuvia, 1998: 5).

\subsection{Gösterişçi Tüketim}

Gösterişçi tüketim kavramı, Veblen'in (1899) ortaya attığı günden itibaren literatürde oldukça fazla ilgi gören en eski tüketici davranışlarından birisidir. Veblen kitabında gösterişçi tüketimi, gereksiz ve verimsiz faaliyetlere zaman ve para harcama davranışı olarak tanımlamıştır. Gösteriş yapmak için yapılan tüketim, hayatta kalmak için değil, kendini diğerlerine karşı zengin ve sosyal duruşu yüksek olarak tanımlamak için belirli mal ve hizmetleri satın alma eyleminidir (Vohra, 2016: 55). Sahip olunan zenginlik ve güç diğer insanların saygısını kazanmak için yeterli değildir. Bu zenginliğin 
gösterilmesi gerekir (Şahin ve Nasır, 2019: 387). Bu nedenle tüketicinin toplum içindeki prestijini yükseltmesinin tek yolu, sahip olduğu zenginlikleri ve varlıklarını dikkat çekecek şekilde diğerlerinin görebileceği ortamlarda tüketmesidir (O’Cass ve McEwen, 2004).

Gösterişçi markalar, tamamen dış nedenlerle satın alınan ve serveti işaret etmeye yönelik olanlardır (Truong vd., 2008: 191). Bu nedenle gösterişçi tüketimle statü tüketimi birbirine benzer davranışlar olarak incelenmektedir (Eroğlu, 2016: 259). Araştırmalara göre sosyal statüyü yükseltme isteği, genellikle, gösterişçi tüketimi teşvik eden önemli bir faktördür. Bu görüşü doğrulayan Goldsmith vd. (1996), tüketicinin davranışını etkileyen en önemli güçlerden birinin lüks mal edinerek sosyal statü kazanma istekleri olduğunu belirtmiştir. Podoshen ve Andrzejewski (2012), tüketicilerin sosyal hiyerarşide daha olumlu görülme ümidiyle belirli ürünler satın aldıklarını tespit etmişlerdir. Bu, daha fazla sosyal statüye sahip olmak için gösteriş̧̧i tüketim yapılmasına neden olur. Souiden vd., (2011), farklı kültürlerde gösterişçi tüketimin sosyal durumu doğrudan ve olumlu yönde etkilediğini ve bu nedenle tüketicilerin gösterişçi davranışlarının sosyal statü arzusuyla açıklanabileceğini ortaya koymuştur.

Yaşadığımız dünyada hepimizin ulaşmaya çalıştı̆̆ı hedefleri vardır. Bu hedeflere ulaşma başarımız, diğer insanların gözünde ne kadar başarılı olduğumuzla ilişkilidir. Bu durum genel bir insan içgüdüsü olarak düşünüldüğünde, geçen zaman içinde ürünler değişse de, diğerlerini etkilemek için yapılan tüketim davranışı değişmeyecektir (Chaudhuri vd., 2011: 216). Tüketim bir tür iletişim sistemi olarak da düşünüldüğünden, kişiler, gösterişçi ürünleri tüketerek sadece diğerleriyle değil kendi benlikleriyle de iletişime geçerler. Böylece bir taraftan kişisel isteklerini yerine getirirken diğer taraftan da kimlik ve toplumsal statülerini belirlemiş olurlar (Şeşen ve Şıker, 2019: 3346). Diğer insanlara gönderilen iletişim sinyalinin etkili olması için, ürünlerin üstündeki marka logolarının etkilemeye çalışılan insanlar tarafından kolayca görülmesi gerekir. Bu etki sadece tüketicinin yakın çevresinde olanları değil, karşılaştığı diğer insanları da içerebilir (Berger ve Ward, 2010: 7).

\subsection{Tüketicinin Marka Duygusu}

Marka, birçok farklı rolünün yanında, tüketiciler için bir tür soyut varlık olarak düşünülebilir. Çünkü tüketicilerin markalı ürün satın almaya karar verme sürecinde etkili olan duygusal faktörlerin bilişsel faktörler kadar etkili olduğu düşünülmektedir (Afif vd., 2015: 337). Duygu kavramı ise "belirli nesne, olay veya bireylerin insanın iç dünyasında uyandırdığı izlenim” ş̧eklinde tanımlanmaktadır (www.tdk.gov.tr, 2019). Bu durumda marka duygusu, tüketiciler ve marka arasındaki ilişkileri açıklamaya yardımcı olan ve tüketicilerin marka için genel değerlendirmesi olarak kabul edilebilir (Geçti ve Zengin, 2013: 112). Başka bir ifadeyle, tüketici açısından marka duygusu kavramı, bir markalı ürünün kullanımı sonucu tüketicide olumlu bir duygusal tepki (mutlu, iyi ve keyifli hissetmek gibi) ortaya çıkarması olarak tanımlanabilir (Chaudhuri, ve Holbrook, 2001: 82). Literatürde, tüketicinin marka duygusunun yüksek olduğu durumlarda marka sadakatinin de yüksek olduğu belirtilir (Kabadayı ve Alan, 2012). Çünkü marka duygusunun, markaya yönelik tutumsal ve davranışsal eğilimleri yönlendirme konusunda oldukça fazla etkisi olduğu düşünülmektedir (Dick ve Basu, 1994: 102).

Duygular, özellikle yoğun ve kalıcı olan belirli nedensel uyarıcılara verilen yanıtlardır. Marka duygusu ise tüketicilerin markalı ürün seçerken, genellikle herhangi bir nitelik bilgisi aramadığı sadece markalı ürün açısından olumlu duygusal etkinin olup olmadığını aradığı anlaşılmaktadır. Bu nedenle marka duygusu, tüketici davranışının öznel hedonik yönünü ifade eder. Bir ürünün öznel hedonik potansiyeli ne kadar yüksek olursa, tüketicide olumlu duygusal tepkisinin de ortaya çıkma potansiyeli o kadar yüksek olabilir (Matzler vd., 2006: 428).

Tüketiciler, markalı ürünleri kullanarak kendilerini ifade ettiklerini düşünürler. Kendini ifade etme sırasında ve sonrasında, markalı ürünler, tüketiciler için olumlu duygusal hisler yaratır. Yaşanan olumlu duygular, tüketicinin gelecekte yapacağ 1 tüketim faaliyetlerinin planlanmasına da rehberlik edebilir (Assimos vd., 2019: 354). Ürünün tekrarlı kullanımı, marka duygusunun da giderek yüksek hissedilmesine neden olabilir. Bu döngü, belirli bir ürün grubundaki markaya duyulan hazcı veya faydacı tepkinin de katlanarak çoğalmasına neden olabilir. Bu mantıkla düşünüldüğünde, marka duygusunun tecrübe edildikçe güçlenen, spontane, anlık ve sezgisel bir süreç olduğu söylenebilir (Chaudhuri, ve Holbrook, 2002: 41).

\section{Araştırma Modelleri ve Hipotezler}

Tüketicinin dış görünümde markalı ürün kullanma bilinci ve gösterişçi tüketim ilişkisi

Dış görünümde markalı ürün kullanma bilinci, temelde sosyal benlik oluşturma konusu olduğundan servet, sosyal ağ ve otorite yoluyla elde edilen olumlu imajı kişisel nitelikler olarak ifade eder (Jiang ve Shan, 2016: 185). Dolayısıyla diş görünümde markalı ürün kullanma bilinci güçlü bir tüketici gösterişçi tüketim yapabilir. Çünkü markalı ürünler, markanın yüksek tanınırlığı sayesinde, tüketiciye güçlü bir sosyal benlik oluşturabilecek olumlu imaja kavuşacağı dış görünüme sahip olmasına yardımcı olabilir (Wong ve Ahuvia, 1998: 4). Dış görünüm bilinci yüksek olan bireyler, kendi imajları kadar diğer insanlardan aldıkları toplumsal takdirlerle de ilgilenirler. Bu nedenle sosyal statülerini artırmak için markalı ürünler satın almaya daha meyilli olabilir (Aziz ve Habib, 2017: 62; Li vd., 2018: 623). Bu nedenle dış görünüşüne önem verme bilinci yüksek olan tüketiciler için markalı ürünleri tüketmek gösteriş yapmak ve başkaları tarafından fark edilmenin en iyi yoludur ( $\mathrm{Li}$ ve Su, 2007: 244; Liao ve Wang, 2009: 991). Dış görünümde markalı ürün kullanma bilinci zayıf olan tüketiciler, ürünlerin kendine özgü özellikleri (kalite gibi) nedeniyle satın alma düşüncesiyle hareket edebilirler. Diğer taraftan dış görünümde markalı ürün kullanma bilinci güçlü olan tüketiciler, ürünlerin dışsal özellikleri (marka ve itibar gibi) nedeniyle satın alma bilinciyle hareket edebilirler. Bu durumda ürünlerin dışsal özelliklerini ön planda tutan, 
dış görünümde markalı ürün kullanma bilinci yüksek tüketiciler ile gösterişçi tüketim arasında yakın ilişki olduğu düşünülebilir (Zhang ve Wang, 2019: 8).

Yapılan açıklamalar ışığında aşağıdaki hipotez geliştirilmiştir:

H1: Tüketicinin dış görünümde markalı ürün kullanma bilincinin gösterişçi tüketim üzerinde olumlu etkisi vardır.

Tüketicinin dış görünümde markalı ürün kullanma bilinci ve gösterişçi tüketim ilişkisinde, marka duygusunun düzenleyici etkisi

Dış görünümünde markalı ürün kullanma bilincinde olan tüketici, markalı ürün satın almak için daha fazla ödemeye istekli olabilir. Çünkü bu tür tüketiciler, markalı ürün kullanmanın karşılığında elde ettiği olumlu duygusal etkiyi başka hiçbir alternatifle elde edemezler (Chaudhuri, ve Holbrook, 2001: 81). Markaya ilişkin duyguların, markaya ilişkin diğer değişkenlerden farklı olarak incelenmesi gereklidir. Çünkü marka duygusu, tecrübe edildikçe güçlenen ve marka bağlılığını ortaya çıkaran önemli değişkenlerden birisidir. Yani marka duygusunun, markalı ürün kullanma sonucunda ortaya çıkan olumlu duyguları yeniden uyandırdığı iddia edilir. Dolayısıyla marka duygusu yüksek olan tüketici, kısa vadede benzer davranışlar sergileme eğilimi içine girecektir (Chaudhuri, ve Holbrook, 2002: 42). Benzer şekilde, daha fazla mutlu ve eğlenceli hissettiren marka duygusu, tüketicinin dış görünümde de markalı ürün kullanma bilinciyle hareket etmesine ve sonuçta daha fazla gösterișçi tüketim yapmasına neden olacaktır. Literatürde marka duygusu önemli bir aracı değişken olarak incelenmektedir. Örneğin Mazodier ve Merunka (2012), 2008 y1lı yaz olimpiyatları ve 2009 Ocak ayı k1ş olimpiyatlarına sponsor olan markaların, tüketiciler üzerindeki marka duygusunu nasıl etkilediğini belirlemeye çalışmıştır. Sonuca göre tüketicilerin marka duygusu, sponsorluk ve marka bağlılığı ilişkisinde aracılık etkisi göstermektedir.

Yapılan açıklamalar 1şı̆̆ında aşağıdaki hipotez geliştirilmiştir:

H2: Tüketicinin dış görünümde markalı ürün kullanma bilincinin gösterişçi tüketim üzerinde olumlu etkisinde, marka duygusunun düzenleyici etkisi vardır.

Tüketicinin dış görünümde markalı ürün kullanma bilinci ve gösterişçi tüketim ilişkisinde, marka duygusunun düzenleyici etkisinin cinsiyete göre değişimi

Tüketiciler karar verme aşamasında duygularından ve bilincinden yararlanırlar. Markalı ürün satın alırken de duygu ve bilinç kullanım derecesi cinsiyetler açısından farklı olabilir (Melnyk vd., 2009: 82). Tüketicinin dış görünümde markalı ürün kullanması, bilinçli olarak yapılan, bir tür kişilerarası iletişim aracı olarak değerlendirilir (Liao ve Wang, 2009: 991). Özellikle toplumsal kültüre yakın tüketicilerde, kişilerarası etkinin duygusal tarafi ağır bastığından, grup normlarına veya grup hedeflerine daha fazla değer verilmesi beklenir (Wong ve Ahuvia, 1998: 10). Dolayısıla, tüketicilerin toplumsal kültüre yakın olanlarla bireyci kültüre yakın olanlar arasında, marka duygusu bakımından da farklılık olması beklenebilir (Sahay vd., 2012: 37). Bu düşünceyi destekler şekilde; Tokgöz'ün (2019: 290) genç tüketicilerin kişilerarası etkiye duyarlılığı üzerine yaptığı araştırmada; kadınların bireyci tüketim kültürüne yakın oldukları, erkeklerin ise toplumsal tüketim kültürüne yakın oldukları sonucuna ulaşmıştır. Başka bir araştırmada toplumsal tüketim kültürüne yakın Çin'de, Li ve diğerlerinin (2015) 192 yüksek lisans öğrencisi üzerinde yaptığg araştırmada; erkek tüketicilerin dış görünüme önem verme bilincinin, kadın tüketicilere kıyasla, anlamlı ve olumlu bir şekilde yüksek olduğunu belirlemiştir.

Yapılan açıklamalar ışı̆̆ında aşağıdaki hipotez geliştirilmiştir:

H3: Tüketicinin dış görünümde markalı ürün kullanma bilincinin gösterişçi tüketim üzerinde olumlu etkisinde, marka duygusunun düzenleyici etkisi cinsiyete göre değişmektedir. 
Tokgöz, E. / Journal of Yasar University, 2020, 15/59, 584-597

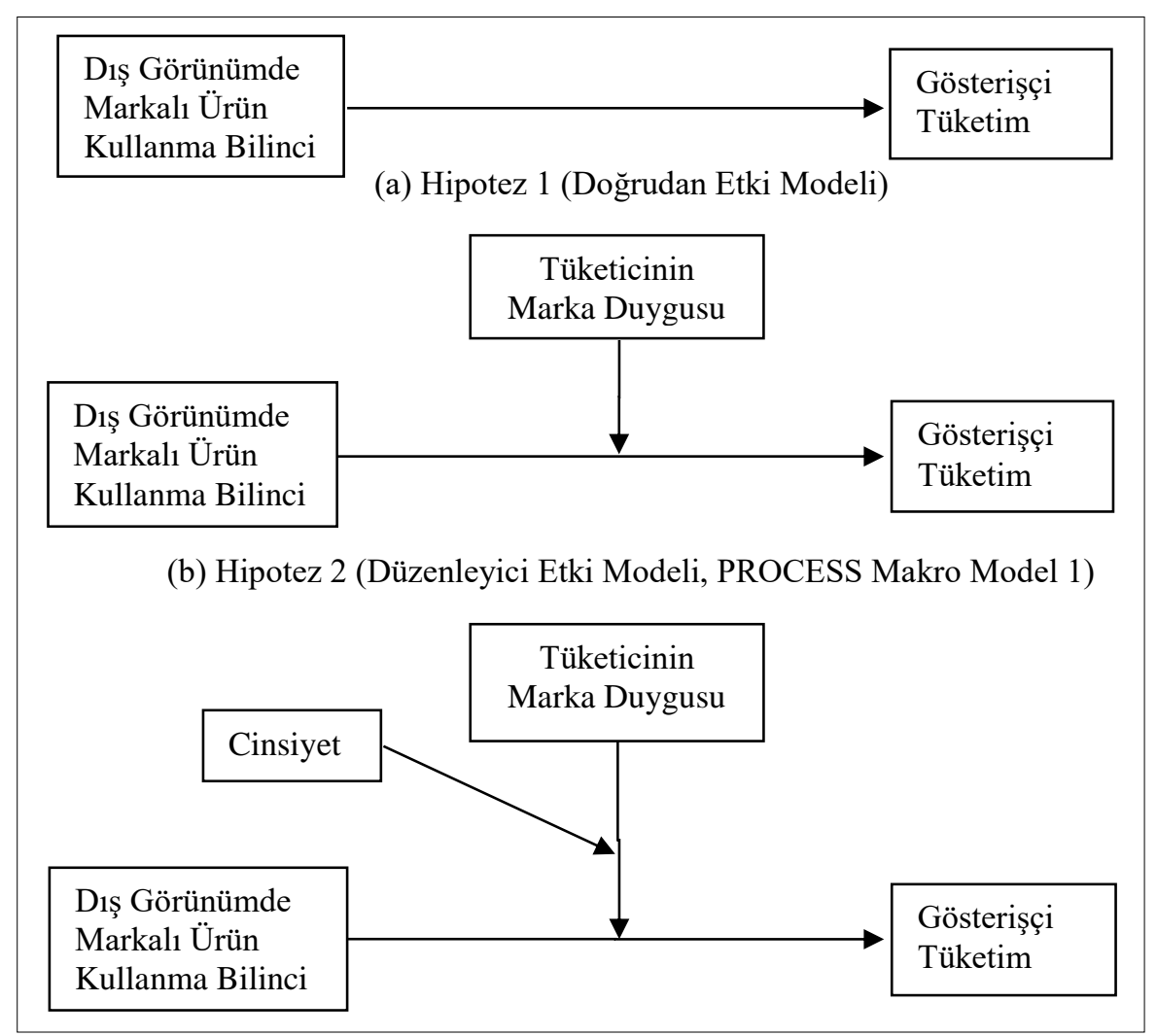

(c) Hipotez 3 (Düzenleyici Etki Modeli, PROCESS Makro Model 3)

Şekil 1. Araştırma Modelleri

Şekil 1'de görüldüğü gibi araştırma modelleri çizilmiştir. Tüketicinin dış görünümde markalı ürün kullanma bilincinin gösterişçi tüketim üzerindeki doğrudan etkisi (Şekil 1a), SPSS programında regresyon analizi yardımıyla yapılacaktır. Tüketicinin dış görünümde markalı ürün kullanma bilincinin gösterişçi tüketim üzerindeki doğrudan etkisinde, marka duygusunun düzenleyici etkisini (Şekil 1b) belirlemek için Hayes (2013) tarafından (www.processmacro.org) oluşturulan ve SPSS programına yüklenerek kullanılan PROCESS makrosu (makro model 1) kullanılacaktır. Tüketicinin dış görünümde markalı ürün kullanma bilincinin gösteriş̧̧i tüketim üzerindeki doğrudan etkisinde, marka duygusunun düzenleyici etkisinin cinsiyete göre değişip değişmediğini (Şekil 1c) belirlemek için Hayes (2013) tarafindan oluşturulan ve SPSS programına yüklenerek kullanılan PROCESS makrosu (makro model 3) kullanılacaktır. Hayes'in (2013) oluşturduğu 92 şablon modelden oluşan makro yardımıyla aracılık testi yapmak mümkündür. Şekil 1'de araştırmaya ait doğrudan ve düzenleyici etki modelleri verilmiştir. Düzenleyicilik analizi, nedensel bir etkinin işleyiş mekanizmaları hakkındaki hipotezleri test etmek için kullanılmaktadır (Hayes, Montoya ve Rockwood, 2017: 76).

Bir düzenleyici model, X (dış görünümde markalı ürün kullanma bilinci) ve Y (gösterişçi tüketim) gibi aralarında nedensel bir ilişki olan iki değişken ve bu değişkenler arasındaki ilişkiyi düzenleyen, en azından $\mathrm{M}$ (marka duygusu) gibi bir aracı değişkeni içerir. Böylece, X'in Y üzerindeki etkisini, M gibi bir değişken düzenlemiş olur. M gibi bir düzenleyici değişkenin, farklı kategorik seviyelerde düzenleyici etkisinin varlığını araştırmak için W (cinsiyet) gibi diğer aracı değişken kullanılmaktadır. Düzenleyici etki modelleri test edilirken; X'in Y üzerindeki etkisi, M'nin Y üzerindeki etkisi ve X ile M çarpımıyla elde edilen etkileşim değişkeninin Y üzerindeki etkisi hesaplanır. Hesaplama yapılırken temel bağımsız değişsken ile düzenleyici değişkenin merkezlenmesi gereklidir. Burada önemli olan etkileşim değişkeninin (X x M) Y üzerindeki etkisinin istatistiksel olarak anlamlı olmasıdır. Diğer yolların hipotezleri burada test edilmediğinden anlamlı olması aranmaz (Burmaoğlu, Polat ve Meydan, 2013: 15).

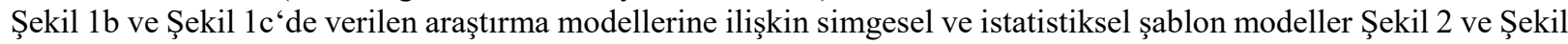
3 'te verilmiştir. Simgesel modellerde; temel bağımsız değişken, tüketicinin dış görünümde markalı ürün kullanma bilinci olarak belirlenmiştir. Düzenleyici değişken, marka duygusu olarak belirlenmiştir. Bağımlı değişken, gösterişçi tüketim olarak belirlenmiş̧ir. Düzenleyici değişkeni düzenleyen diğer düzenleyici değişken ise cinsiyet olarak belirlenmiştir.

Şekil 2'deki istatistiksel model çalıştırıldığında, marka duygusu seviyesi ortalamasının; bir standart sapma üstü, ortalaması ve bir standart sapma altında olan tüketiciler açısından, tüketicinin dış görünümde markalı ürün kullanma bilincinin gösteriş̧̧i tüketim üzerindeki etkisinin anlamlı şekilde değişip değişmediği belirlenmiş olacaktır. Şekil 3'teki istatistiksel model çalıştırıldığında ise Şekil 2'de elde edilen sonuçların cinsiyet açısından anlamlı bir farklılık gösterip göstermediği belirlenmiş olacaktır.

Şekil 1a'da görüldüğü gibi basit regresyon analizi yapılarak elde edilen sonuç aynı zamanda araştırmanın Hipotez 1'ini de sınamış olacaktır. Şekil $1 \mathrm{~b}$ 'de görüldüğü gibi, temel bağımsız değişken ile bağımlı değişken arasındaki ilişkide marka duygusunun düzenleyici etki gösterip göstermeyeceği, Şekil 2'deki istatistiksel model yardımıyla PROCESS 
makro model 1 kullanılarak yapılacaktır. Elde edilen sonuç aynı zamanda araştırmanın Hipotez 2'sini de sınamış olacaktır. Şekil 1c'de görüldüğü gibi, temel bağımsız değişken ile bağımlı değişken arasındaki ilişkide marka duygusunun düzenleyici etkisinin cinsiyet açısından değişiklik gösterip göstermeyeceği, Şekil 3'teki istatistiksel model yardımıyla PROCESS makro model 3 kullanılarak yapılacaktır. Elde edilen sonuç aynı zamanda araştırmanın Hipotez 3'ünü de sınamış olacaktır.

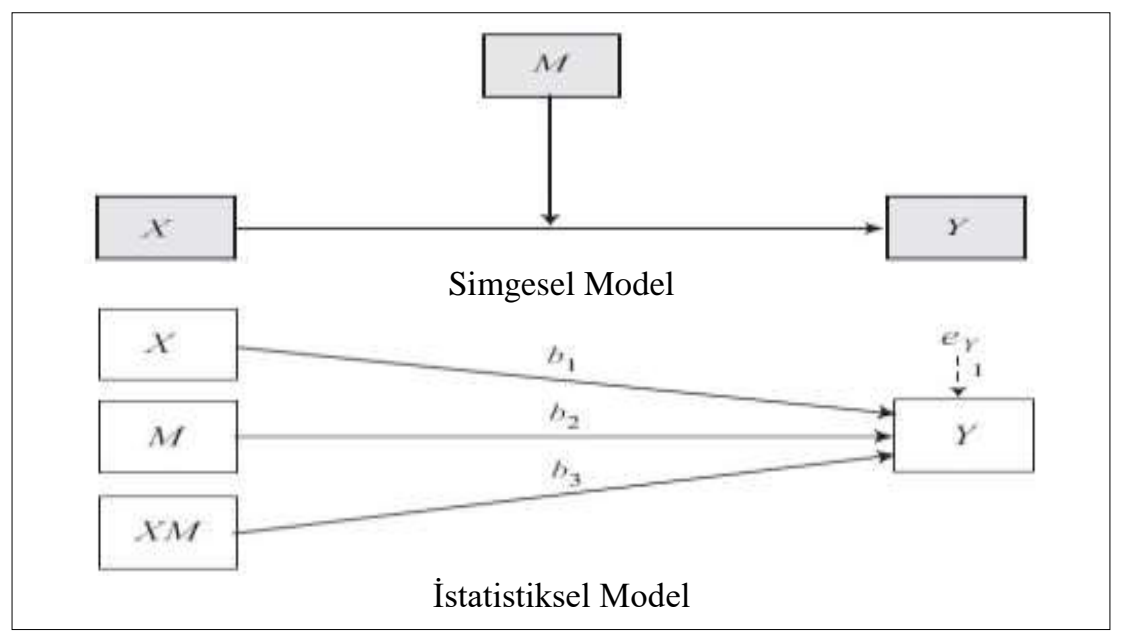

Şekil 2. Araştırma Modeli 1b İçin Simgesel ve İstatistiksel Model

(PROCESS Makro Model 1)

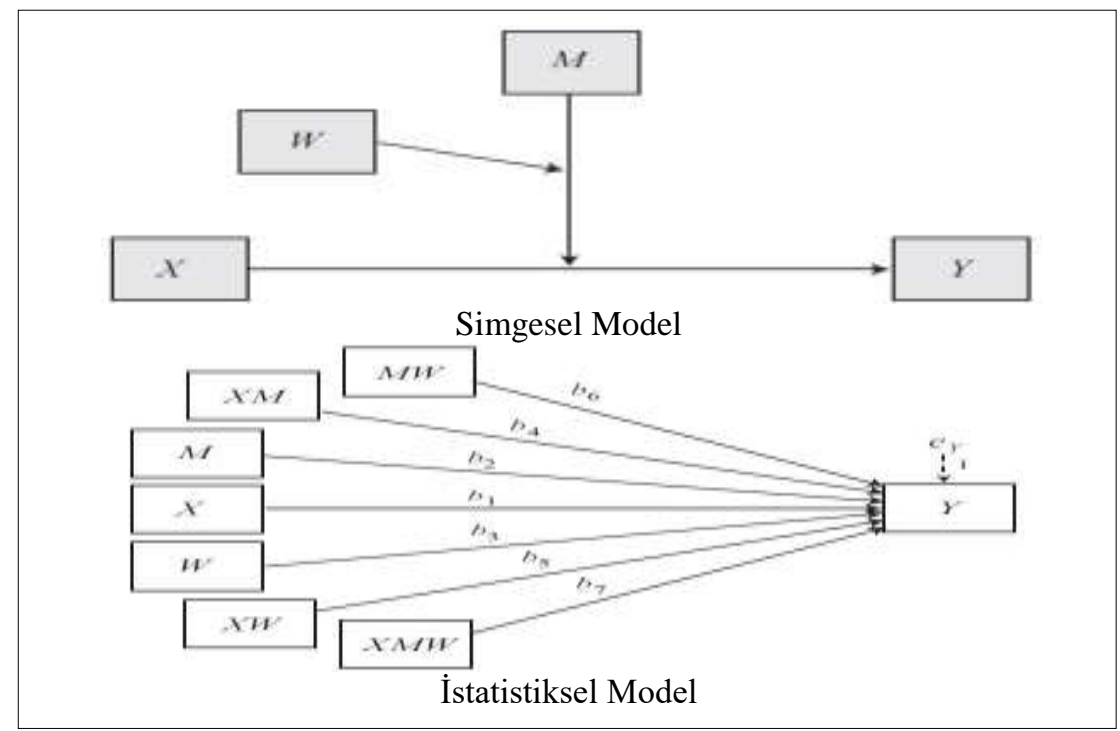

Şekil 3. Araştırma Modeli 1c İçin Simgesel ve İstatistiksel Model

(PROCESS Makro Model 3)

\section{Yöntem}

\subsection{Veri Toplama ve Örneklem}

Araştırmada olasılığa dayalı olmayan örnekleme yöntemlerinden kolayda örnekleme yöntemi (Kozak, 2015: 116) kullanılmış ve gerekli verilerin toplanması için 5'li likert derecelemesinden yararlanılarak anket formu oluşturulmuştur (Aziz, 2008: 93; Nakip, 2013: 200). Anket, Çanakkale Onsekiz Mart Üniversitesinde okuyan öğrencilere uygulanmış ve örneklem büyüklüğünün varyansı maksimum kılan oran dikkate alınarak \% 5 anlam düzeyinde ve \% 5 örneklem hatası ile 384 katılımcının yeterli olacağı tespit edilmiştir (Büyüköztürk ve diğerleri, 2009: 96).

Oluşturulan anket formunda 3 adet ölçek bulunmaktadır. Tüketicinin marka duygusu ölçeği Chaudhuri ve Holbrook'un (2001) geliştirdiği 3 maddeli bir ölçek ile belirlenmiştir. Gösterişçi tüketim ölçeği O’Cass ve McEwen'ın (2004) geliştirdiği 6 maddeli bir ölçek ile belirlenmiştir. Tüketicinin dış görünümde markalı ürün kullanma bilinci ölçeği Bao ve diğerlerinin (2003) geliştirdiği 4 maddeli bir ölçek ile belirlenmiştir. 


\section{Araştırma Bulguları}

Veri analizi çok değişkenli istatistik teknikleri kullanılarak yapılmıştır. değişkenler uç değerler açısından incelenmiştir. Her değişkenin mahalanobis (D2) mesafesi hesaplanmıştır, daha sonra değişkenin serbestlik derecesine (df = değişkenin sahip olduğu madde sayısı) bölünerek (D2 / df) elde edilen değer, 0,01 anlamlılık seviyesinde t dağ1lım tablosundaki değerle karşılaştırılmıştır. T dağılım tablosundan büyük olan gözlemler, uç değer olarak belirlenip silinmiştir (Hair vd., 2010: 64).

Tüketicinin marka duygusu değişkenine ait mahalanobis değerleri hesaplanmıştır. Mahalanobis değerleri (D2), değişkenlerin sahip olduğu serbestlik derecesine $(\mathrm{df}=3)$ bölünmüş ve t dağılım tablosunda 3 serberstlik derecesi değeri olan 5,841'den (Laurencelle ve François-A 2002:19) büyük olup olmadığ kontrol edilmiştir. Tüketicinin diş görünümde markalı ürün kullanma bilinci değişkeni için D2 / df $(\mathrm{df}=4)$ değeri 4,604'den büyük olup olmadığ1 kontrol edilmiştir. Gösterişçi tüketim değişkeni için D2 / df $(\mathrm{df}=6)$ değeri 3,707'den büyük olup olmadığ1 kontrol edilmiştir. Her üç değişken için yapılan hesaplamada, $t$ değişim tablosundan büyük olan gözlemler silinmiştir. Ölçeklerden uç değerler çıkarılması sonucunda, kullanılabilir durumda 454 anket üzerinden analizler yapılmıştır.

Örneklemi oluşturan katılımcıların demografik özellikleri Tablo 1'de verilmiştir. Katılımcılar 17-28 yaşlarında, 272'si erkek, 155'inin aile geliri 2001-3000 TL arasında, 327'sine aylık 1000 TL'den az harçlık gelmekte, 268'inin yaşantısı şehir merkezinde geçmiş ve 253'ünün ailesi Marmara Bölgesinde ikamet etmektedir.

Tablo 1. Katılımcıların Demografik Özelliklerinin Dağılımı (N=454)

\begin{tabular}{|c|c|c|c|c|c|}
\hline Demografik Özellikler & Frekans & Yüzde \% & Demografik Özellikler & Frekans & Yüzde \% \\
\hline Ailenin Geliri & & & Cinsiyet & & \\
\hline 2000 TL'den az & 127 & 28,0 & Erkek & 272 & 59,9 \\
\hline 2001-3000TL & 155 & 34,1 & Kadın & 182 & 40,1 \\
\hline 3001-4000TL & 74 & 16,3 & Yaş & & \\
\hline 4001-5000TL & 44 & 9,7 & 17 & 3 & 0,7 \\
\hline 5001-6000TL & 23 & 5,1 & 18 & 98 & 21,6 \\
\hline 6001TL üstü & 31 & 6,8 & 19 & 162 & 35,7 \\
\hline Gelen Harçlık & & & 20 & 108 & 23,8 \\
\hline 1000 TL'den az & 327 & 72,0 & 21 & 52 & 11,5 \\
\hline 1001-1500TL & 89 & 19,6 & 22 & 16 & 3,5 \\
\hline 1501-2000TL & 21 & 4,6 & 23 & 10 & 2,2 \\
\hline 2001-2500TL & 4 & 0,9 & 24 & 4 & 0,9 \\
\hline 2501-3000TL & 6 & 1,3 & 28 & 1 & 0,2 \\
\hline 3001TL üstü & 7 & 1,5 & Ailenin Yaşadı̆̆ Bölge & & \\
\hline Yaşamın Geçtiği Bölge & & & Ege & 80 & 17,6 \\
\hline Şehir Merkezi & 268 & 59,0 & Akdeniz & 24 & 5,3 \\
\hline İlçe & 129 & 28,4 & Karadeniz & 38 & 8,4 \\
\hline Belde & 19 & 4,2 & Marmara & 253 & 56,7 \\
\hline Köy & 36 & 7,9 & İç Anadolu & 32 & 7,0 \\
\hline Yurtdış1 & 2 & 0,4 & Doğu Anadolu & 13 & 2,9 \\
\hline & & & G.D. Anadolu & 8 & 1,8 \\
\hline & & & Yurt Diş1 & 6 & 1,3 \\
\hline
\end{tabular}

Doğrulayıcı Faktör Analizi: Araştırma kapsamını oluşturan ölçeklere doğrulayıcı faktör analizi yapılmıştır. Doğrulayıcı faktör analiziyle, değişkenlere ait düşük yüklenme katsayısı varlığı ve elde edilen model uyum değerlerinin iyi seviyede olup olmadığı araştırılmıştır. Tablo 2'de, değişkenler arasındaki korelasyon, t değerleri, çıkarılan ortalama varyans (AVE), birleşik güvenirlik (CR) sonuçlarına ve Tablo 3'de, doğrulayıcı faktör analizi standart faktör yüklerine ve katılımcıların ölçekte yer alan maddelere verdikleri puanların betimleyici istatistiklerine ulaşılmıştır.

Tablo 2. Değişkenler Arasındaki Korelasyon, t Değerleri ve Güvenirlik Test Sonuçları

\begin{tabular}{|l|c|c|c|c|c|}
\hline & 1 & 2 & 3 & $\begin{array}{c}\text { Çıarılan } \\
\text { Ortalama } \\
\text { Varyans }(A V E)\end{array}$ & $\begin{array}{c}\text { Birleşik } \\
\text { Güvenirlik } \\
(\text { CR })\end{array}$ \\
\hline 1. Tüketicinin Marka Duygusu & 1 & & & 0,86 & 0,95 \\
\hline 2. Gösterişçi Tüketim & $\begin{array}{c}0,47 \\
(8,02)\end{array}$ & 1 & & 0,67 & 0,92 \\
\hline $\begin{array}{l}\text { 3. Tüketicinin Dış Görünümde } \\
\text { Markalı Ürün Kullanma Bilinci }\end{array}$ & $\begin{array}{c}0,36 \\
(6,40)\end{array}$ & $\begin{array}{c}0,68 \\
(9,11)\end{array}$ & 1 & 0,62 & 0,86 \\
\hline
\end{tabular}


Chi-Square=211; df=62; p-value=0,0000; RMSEA=0,073; Chi-Square / df=3,40; NFI=0,98;

$\mathrm{CFI}=0,98 ; \mathrm{GFI}=0,93 ; \mathrm{AGFI}=0,90 ; \mathrm{SRMR}=0,040$

Parantez içindekiler $\mathrm{t}$ değerleridir.

Tablo 2'de görüldüğü gibi, uyuşma geçerliliği (convergent validity) için her bir saklı değişkenin ayrı ayrı Çıkarılan Ortalama Varyans (Average Variance Extracted-AVE) ve Bileşik Güvenilirlik (Composite Reliability-CR) değerlerine bakılmıştır. Uyuşma geçerliliği için; AVE değerinin 0,5'ten, CR değerinin 0,70'den ve CR oranının da AVE'den büyük olması gerekmektedir (CR>0,7; AVE $>0,5$; CR $>$ AVE) (Diamantopoulos ve Siguaw, 2000: 90). Yap1lan incelemede, ölçeklerin uyuşma geçerliliği için gerekli şartları sağladığı görüldükten sonra ayrışma geçerliliği de (discriminant) test edilmiştir. Ayrışma geçerliliği için, her bir faktöre ait AVE değerinin, her bir değişkenin diğer değişkenlerle olan korelasyonlarının karesinden daha yüksek olması gerekmektedir (Fornell ve Larcker, 1981: 46). Yapılan hesaplama sonucu, AVE değerlerinin korelasyon değerlerinin karesinden yüksek olduğu görüldüğünden, ölçekler ayrışma geçerliliğini sağlamaktadır.

Tablo 3. Doğrulayıcı Faktör Analizi ve Ölçeklerin Betimleyici İstatistikleri

\begin{tabular}{|c|c|c|c|c|c|}
\hline Ölçekler & Ort. & $\begin{array}{l}\text { Std. } \\
\text { Sapma }\end{array}$ & $\stackrel{t}{\text { değgeri }}$ & $\begin{array}{c}\text { Standart } \\
\text { Faktör } \\
\text { Yükleri }\end{array}$ & $\begin{array}{l}\text { Hata } \\
\text { Varyansl }\end{array}$ \\
\hline \multicolumn{6}{|l|}{ Tüketicinin Marka Duygusu } \\
\hline Markalı ürünler kullandığımda iyi hissederim & 2,78 & 1,23 & $\mathrm{fp}$. & 0,90 & 0,18 \\
\hline Markalı ürünler kullandığımda mutlu olurum & 2,83 & 1,24 & 38,59 & 0,98 & 0,03 \\
\hline Markalı ürünler kullanmak bana keyif verir & 2,81 & 1,28 & 31,67 & 0,91 & 0,18 \\
\hline Ölçek Ortalaması & 2,80 & & & & \\
\hline \multicolumn{6}{|l|}{ Gösterişçi Tüketim } \\
\hline $\begin{array}{l}\text { Satın aldığım ürünleri kullanırken, diğer insanlar tarafından } \\
\text { farkedilmek isterim }\end{array}$ & 2,26 & 1,13 & fp. & 0,72 & 0,49 \\
\hline $\begin{array}{l}\text { Alışveriş yaparken çevremde başkalarının olup olmaması benim } \\
\text { için önemlidir }\end{array}$ & 2,33 & 1,16 & 15,22 & 0,73 & 0,46 \\
\hline Satın aldığım ürün ve markalarla saygı kazanmak isterim & 2,12 & 1,16 & 18,06 & 0,87 & 0,25 \\
\hline $\begin{array}{l}\text { Satın aldığım ürün ve markalarla popüleritemin artmasını } \\
\text { isterim }\end{array}$ & 2,05 & 1,13 & 18,75 & 0,90 & 0,19 \\
\hline $\begin{array}{l}\text { Satın aldığım ürün ve markalarla insanlara nasıl birisi olduğumu } \\
\text { gösteririrm }\end{array}$ & 2,09 & 1,13 & 17,15 & 0,82 & 0,32 \\
\hline $\begin{array}{l}\text { Satın aldığım ürün ve markaları başkalarının görmesi benim } \\
\text { için önemlidir }\end{array}$ & 2,03 & 1,15 & 18,02 & 0,87 & 0,25 \\
\hline Ölçek Ortalaması & 2,15 & & & & \\
\hline \multicolumn{6}{|l|}{ Tüketicinin Dış Görünümde Markalı Ürün Kullanma Bilinci } \\
\hline $\begin{array}{l}\text { Satın aldığım ürünlerin markalarını diğerlerinin sevmesi benim } \\
\text { için önemlidir }\end{array}$ & 2,29 & 1,11 & fp. & 0,74 & 0,45 \\
\hline $\begin{array}{l}\text { Bazen arkadaşlarım satın aldığı için satın aldığım markalar } \\
\text { vardır }\end{array}$ & 1,99 & 1,09 & 16,33 & 0,80 & 0,36 \\
\hline $\begin{array}{l}\text { Markalı ürünleri satın almak, insanları diğer insanlardan } \\
\text { ayırmanın güzel bir yoludur }\end{array}$ & 1,77 & 1,05 & 16,43 & 0,81 & 0,35 \\
\hline Markalı ürünler satın almak bana prestij duygusu verir & 1,93 & 1,06 & 16,27 & 0,80 & 0,36 \\
\hline Ölçek Ortalaması & 2,00 & & & & \\
\hline
\end{tabular}

Hipotezlerin test edilmesi: Şekil 1(a)'da simgesel olarak gösterilen araştırma modelinde; tüketicinin diş görünümde markalı ürün kullanma bilincinin gösterişçi tüketim üzerindeki doğrudan etkisini belirlemeye yönelik oluşturulan Hipotez 1'i test etmek için basit regresyon analizi yapılmıştır. Tablo 4'de görüldüğü gibi tüketicinin dış görünümde markalı ürün kullanma bilincinin gösterişçi tüketim üzerinde anlamlı ve olumlu yönde neden sonuç ilişkisi $(\beta=0,65)$ bulunmaktadır. Elde edilen bu sonuçla Hipotez 1 kabul edilmiştir.

Tablo 4. Araştırma Modellerine Ait Regresyon Analizi Sonuçları

\begin{tabular}{|l|c|c|c|}
\hline & \multicolumn{3}{|c|}{ Gösterişçi Tüketim } \\
\hline Değişkenler & Şekil 1a ${ }^{+}$ & Şekil 1b & Şekil 1c $^{+}$ \\
\hline Temel Bağımsız Değişken & & & \\
\hline Diş Görünümde Markalı Ürün Kullanma Bilinci (DGMÜKB) & $0,65^{* *}$ & $0,51^{* *}$ & $0,48^{* *}$ \\
\hline F & 263,63 & & \\
\hline
\end{tabular}


Tokgöz, E. / Journal of Yasar University, 2020, 15/59, 584-597

\begin{tabular}{|c|c|c|c|}
\hline $\mathrm{R}$ & 0,60 & & \\
\hline $\mathrm{R}^{2}$ & 0,36 & & \\
\hline \multicolumn{4}{|l|}{ Düzenleyici Değişkenler } \\
\hline Marka Duygusu (MD) & & $0,24 * *$ & $0,22 * *$ \\
\hline Cinsiyet $(\mathrm{CN})$ & & & $-0,21 * *$ \\
\hline $\mathrm{F}$ & & 140,47 & \\
\hline $\mathrm{R}$ & & 0,67 & \\
\hline $\mathrm{R}^{2}$ & & 0,46 & \\
\hline \multicolumn{4}{|l|}{ Etkileşim Değişkenleri } \\
\hline DGMÜKB x MD & & $0,11 * *$ & $0,08 * *$ \\
\hline DGMÜKB x CN & & & $-0,12$ \\
\hline $\mathrm{MD} \times \mathrm{CN}$ & & & $-0,03$ \\
\hline DGMÜKB x MD x CN & & & $-0,14^{*}$ \\
\hline $\mathrm{F}$ & & & 82,85 \\
\hline $\mathrm{R}$ & & & 0,69 \\
\hline $\mathrm{R}^{2}$ & & & 0,48 \\
\hline \multicolumn{4}{|c|}{$\begin{array}{l}* * 0,01 \text { seviyesinde anlamlı. } \\
* 0,05 \text { seviyesinde anlamlı. } \\
\text { Cinsiyet: } 1=\text { Erkek, } 2=\text { Kadın } \\
{ }^{+} \text {Modellere ait beta katsayıları standartlaştırılmamıştır. }\end{array}$} \\
\hline
\end{tabular}

Şekil 1(b)'de simgesel olarak gösterilen ve Hipotez 2'yi test etmek için kullanılan PROCESS Makro Model 1 çalıştırılmıştır. Tablo 4'de görüldüğü gibi tüketicinin dış görünümde markalı ürün kullanma bilincinin (temel bağımsız değişken) gösterişçi tüketim (bağımlı değişken) üzerindeki etkisini gösteren yola düzenleyici etki gösterecek marka duygusu (düzenleyici değişken) ile temel bağımsız değişken ve düzenleyici değişkenin çarpılmasıyla bulunan etkileşim değişkeni (DGMÜKB x MD) eklenmiştir. Analiz sonuçlarına göre tüketicinin dış görünümde markalı ürün kullanma bilincinin $(\beta=0,51)$ ve marka duygusunun $(\beta=0,24)$ gösterişçi tüketim üzerinde anlamlı ve olumlu yönde etkisi olduğu, etkileşim teriminin (DGMÜKB x MD; $\beta=0,11$ ) gösterişçi tüketim üzerinde anlamlı ve olumlu yönde etkisi olduğu anlaşılmıştır.

Tablo 5'de görüldüğü gibi Şekil 1b'ye ait PROCESS Makro Model çıktı dosyası incelendiğinde, tüketicinin diş görünümde markalı ürün kullanma bilincinin gösterişçi tüketim üzerindeki etkisinin, marka duygusu seviyesi 1 standart sapma altında ( -1 std. sapma) olanların $\beta=0,38$ seviyesinde olduğu, ortalama seviyede (sıfır) olan tüketicilerin $\beta=0,51$ seviyesine yükseldiği ve 1 standart sapma üstünde (+1 std. sapma) olan tüketiciler için en yüksek seviyede $(\beta=0,65)$ olduğu görülmüştür. Dolayısıyla, tüketicinin dış görünümde markalı ürün kullanma bilincinin gösterişçi tüketim üzerindeki etkisi; marka duygusu seviyesi yüksek olan tüketicilerde daha fazla olduğu anlaşılmıştır.

Tablo 5. Marka Duygusunun Durumsal Düzenleyici Etkisi

\begin{tabular}{|c|c|c|c|c|c|c|}
\hline Marka Duygusu & $\begin{array}{c}\text { Katsayı } \\
(\beta)+\end{array}$ & $\begin{array}{c}\text { Std. } \\
\text { Hata }\end{array}$ & $\begin{array}{c}t \\
\text { Değeri }\end{array}$ & $\begin{array}{c}\text { Anlamlılı } \\
(p)\end{array}$ & $\begin{array}{c}\text { Alt Seviye } \\
\text { Güvenirlik } \\
\text { Aralığ } \\
(\text { LLCI })\end{array}$ & $\begin{array}{c}\text { Üst Seviye } \\
\text { Güvenirlik } \\
\text { Aralı̆̆ } \\
(\text { ULCI })\end{array}$ \\
\hline - 1 std. Sapma & 0,38 & 0,055 & 6,88 & 0,0000 & 0,2740 & 0,4929 \\
\hline 0 (sıfir) & 0,51 & 0,041 & 12,55 & 0,0000 & 0,4360 & 0,5978 \\
\hline + 1 std. Sapma & 0,65 & 0,049 & 13,24 & 0,0000 & 0,5538 & 0,7468 \\
\hline+
\end{tabular}

Araştırma kapsamında kullanılan bağımsız değişkenlerin merkezlenmesiyle (Hayes, 2018: 319) çalıştırılan PROCESS Makro Model çıktı dosyasından elde edilen verilerle Grafik 1 çizilmiştir. Grafikten görüldüğü gibi marka duygusu seviyesi ortalamanın bir standart sapma üstünde ( +1 Doğrusu) olan doğrunun $(\beta=0,65)$ eğiminin yüksek olduğu görülmektedir. Marka duygusu seviyesi ortalama (0 doğrusu) olan doğrunun $(\beta=0,51)$ eğiminin giderek düştüğü görülmektedir. Marka duygusu seviyesi ortalamanın bir standart sapma altında ( -1 Doğrusu) olan doğrunun $(\beta=0,38)$ eğiminin en düşük seviyede olduğu görülmektedir. Elde edilen bu sonuçla, dış görünümde markalı ürün kullanma bilinci ile gösterişçi tüketim arasındaki ilişkide marka duygusunun düzenleyici etkisi vardır şeklindeki Hipotez 2 kabul edilmiştir. 


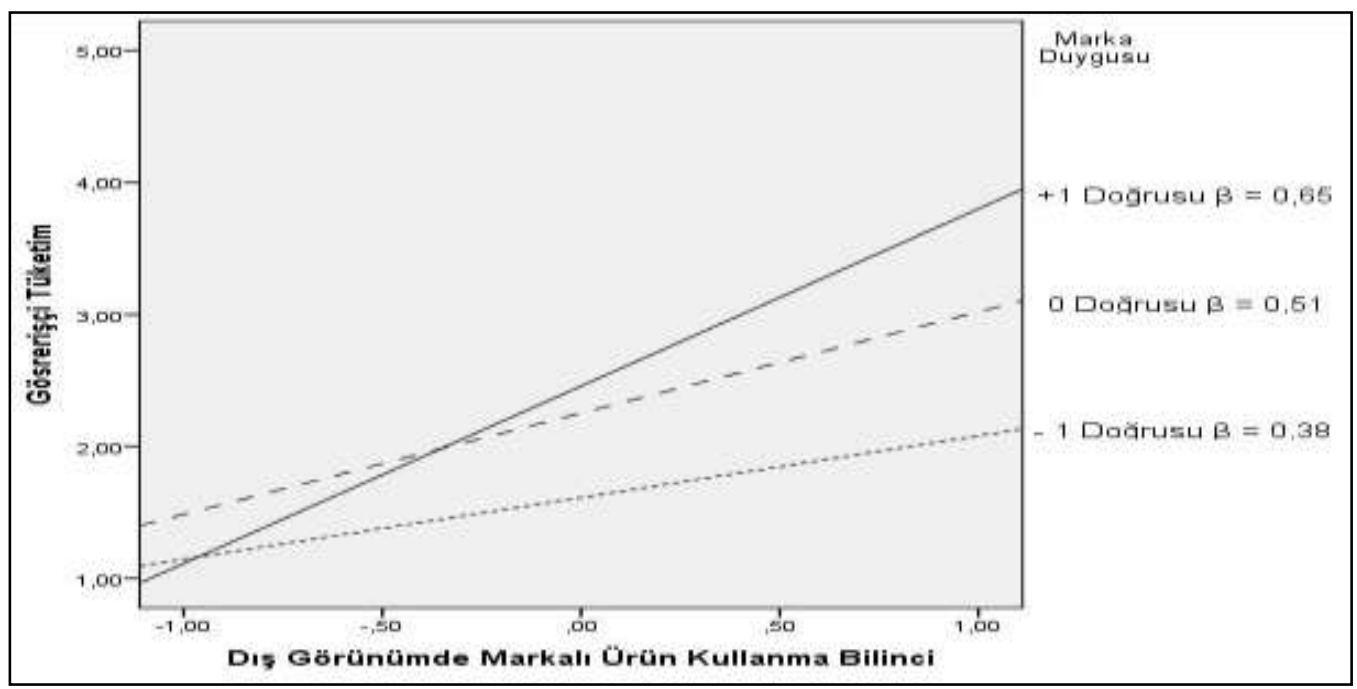

Grafik 1. Tüketicinin Dış Görünümde Markalı Ürün Kullanma Bilincinin Gösterişçi Tüketim Üzerindeki Etkisinde Marka Duygusunun Durumsal Eğim Grafiği

Hipotez 3'ü test etmek için Şekil 1c'de simgesel olarak gösterilen ve Şekil 3'te istatistiksel olarak verilen PROCESS Makro Model 3 çalıştırılmıştır. Tablo 4'te görüldüğü gibi Şekil 1b'de oluşturulan modele, marka duygusu değişkenini düzenleyen cinsiyet $(\mathrm{CN})$ değişkeni eklenmiştir. Bu durumda Şekil 1b'de elde edilen hesaplamalara; dış görünümde markalı ürün kullanma bilinci ve cinsiyetin çarpılmasıyla (DGMÜKB x CN) elde edilen etkileşim değişkeni, marka duygusu ve cinsiyetin çarpılmasıyla elde edilen etkileşim değişkeni ( $\mathrm{MD}$ x CN) ve diş görünümde markalı ürün kullanma bilinci, marka duygusu ve cinsiyetin çarpılmasıyla elde edilen etkileşim değişkeni (DGMÜKB x MD x CN) eklenmiştir.

Analiz sonuçlarına göre temel bağımsız değişken olan dış görünümde markalı ürün kullanma bilincinin gösterişçi tüketim üzerindeki direkt etkisinin devam ettiği $(\beta=0,48)$; Düzenleyici değişkenlerden, marka duygusu değişkeninin gösterişçi tüketim üzerinde direkt etkisinin $(\beta=0,22)$ devam ettiği, cinsiyet değişkeninin gösteriş̧̧i tüketim üzerinde direkt etkisinin $(\beta=-0,21)$ anlamlı olduğu anlaşılmıştır.

Diğer taraftan etkileşim değişkenlerinden; dış görünümde markalı ürün kullanma bilinci ve marka duygusu değişkeni çarpımının (DGMÜKB x MD) gösterişçi tüketim üzerindeki direkt etkisinin devam ettiği $(\beta=0,08)$ anlaşılmaktadır. Dış görünümde markalı ürün kullanma bilinci ve cinsiyet değişkeni çarpımının (DGMÜKB x CN) gösterişçi tüketim üzerindeki direkt etkisinin anlamlı olmadığı $(\beta=-0,12)$ anlaşılmıştır. Marka duygusu ve cinsiyet değişkeni çarpımının $(\mathrm{MD} \times \mathrm{CN})$ gösterişçi tüketim üzerindeki direkt etkisinin anlamlı olmadığı $(\beta=-0,03)$ anlaşılmıştır. Dış görünümde markalı ürün kullanma bilinci, marka duygusu ve cinsiyet değişkenlerinin çarpımının (DGMÜKB x MD x CN) gösterişçi tüketim üzerindeki direkt etkisinin anlamlı olduğu $(\beta=-0,14)$ anlaşılmıştır.

Şekil 1c'ye ait PROCESS Makro Model çıktı dosyasındaki, dış görünümde markalı ürün kullanma bilinci ile marka duygusu etkileşiminin cinsiyet açısından durumsal düzenleyici etkisini gösteren Tablo 6 incelendiğinde; kadın tüketiciler için diş görünümde markalı ürün kullanma bilincinin gösterişçi tüketim üzerindeki etkisinde marka duygusunun düzenleyici etkisinin anlamlı olmadığı $(\beta=-0,008$ ve p değeri $0,882>0,05)$ anlaşılmıştır. Başka bir ifadeyle, kadın tüketicilerin farklı marka duygusu seviyeleri açısından (1 standart sapma altı, ortalama değer ve 1 standart sapma üstü), dış görünümde markalı ürün kullanma bilincinin gösterişçi tüketim üzerindeki etkisi anlamlı şekilde değişmemektedir. Tablo 7'de kadın tüketicilerin, farklı marka duygusu seviyelerinde dış görünümde markalı ürün kullanma bilincinin gösterişçi tüketim üzerindeki etkileri (sırayla $\beta=0,41 ; \beta=0,40$ ve $\beta=0,39$ ) verilmiştir.

Tablo 6. Dış Görünümde Markalı Ürün Kullanma Bilincinin Gösterişçi Tüketim Üzerindeki Etkisinin, Marka Duygusu Etkileşiminin Cinsiyet Açısından Durumsal Düzenleyici Etkisi

\begin{tabular}{|c|c|c|c|c|c|c|}
\hline Cinsiyet & $\begin{array}{c}\text { Katsayı } \\
(\beta)+\end{array}$ & $\begin{array}{c}\text { Standart } \\
\text { Hata }\end{array}$ & $\begin{array}{c}t \\
\text { Değeri }\end{array}$ & $\begin{array}{c}\text { Anlamlılık } \\
(p)\end{array}$ & $\begin{array}{c}\text { Alt Seviye } \\
\text { Güvenirlik } \\
\text { Aralığ } \\
(\text { LLCI })\end{array}$ & $\begin{array}{c}\text { Üst Seviye } \\
\text { Güvenirlik } \\
\text { Aralığ } \\
(\text { ULCI })\end{array}$ \\
\hline Erkek & 0,13 & 0,0354 & 3,91 & 0,000 & 0,0688 & 0,2078 \\
\hline Kadın & $-0,008$ & 0,0550 & $-0,14$ & 0,882 & $-0,1162$ & 0,0999 \\
\hline
\end{tabular}

Erkek tüketiciler açısından Tablo 6 incelendiğinde, dış görünümde markalı ürün kullanma bilincinin gösterişçi tüketim üzerindeki etkisinde marka duygusunun düzenleyici etkisinin anlamlı olduğu $(\beta=0,13$ ve $p$ değeri $0,000<0,05)$ anlaşılmıştır. Başka bir ifadeyle, erkek tüketicilerin farklı marka duygusu seviyeleri açısından (1 standart sapma altı, ortalama değer ve 1 standart sapma üstü), dış görünümde markalı ürün kullanma bilincinin gösterişçi tüketim üzerindeki 
etkisi anlamlı şekilde değişmektedir. Tablo 7'de erkek tüketicilerin, farklı marka duygusu seviyelerinde dış görünümde markalı ürün kullanma bilincinin gösterişçi tüketim üzerindeki etkileri (sırayla $\beta=0,36 ; \beta=0,53$ ve $\beta=0,69$ ) verilmiştir.

Tablo 7. Dış Görünümde Markalı Ürün Kullanma Bilincinin Gösterişçi Tüketim Üzerindeki Etkisinin Cinsiyet Açısından Farklı Seviyelerdeki Marka Duygusunun Düzenleyici Etkisi

\begin{tabular}{|c|c|c|c|c|c|c|c|}
\hline Cinsiyet & $\begin{array}{c}\text { Marka Duygusu } \\
\text { Seviyesi }\end{array}$ & $\begin{array}{c}\text { Katsayl } \\
(\beta)+\end{array}$ & $\begin{array}{l}\text { Standart } \\
\text { Hata }\end{array}$ & $\stackrel{t}{\text { Değeri }}$ & $\begin{array}{l}\text { Anlamlılık } \\
(p)\end{array}$ & $\begin{array}{c}\text { Alt Seviye } \\
\text { Güvenirlik } \\
\text { Aralığ } \\
\text { (LLCI) }\end{array}$ & $\begin{array}{c}\text { Üst Seviye } \\
\text { Güvenirlik } \\
\text { Aralı̆gl } \\
\text { (ULCI) }\end{array}$ \\
\hline Erkek & -1 Std Sapma & 0,36 & 0,071 & 5,11 & 0,000 & 0,2255 & 0,5074 \\
\hline Erkek & 0 (sıfir) & 0,53 & 0,051 & 10,26 & 0,000 & 0,4302 & 0,6340 \\
\hline Erkek & +1 Std Sapma & 0,69 & 0,061 & 11,28 & 0,000 & 0,5762 & 0,8193 \\
\hline Kadın & -1 Std Sapma & 0,41 & 0,108 & 3,82 & 0,000 & 0,2004 & 0,6249 \\
\hline Kadın & 0 (sifir) & 0,40 & 0,074 & 5,42 & 0,000 & 0,2569 & 0,5489 \\
\hline Kadın & +1 Std Sapma & 0,39 & 0,089 & 4,38 & 0,000 & 0,2168 & 0,5694 \\
\hline
\end{tabular}

Araştırma kapsamında kullanılan bağımsız değişkenlerin merkezlenmesiyle (Hayes, 2018: 319) çalıştırılan PROCESS Makro Model çıktı dosyasından elde edilen veriler, Grafik 2'de görüldügüu gibi cinsiyete göre ayrı ayrı çizilmiştir. Grafikten görüldüğü gibi kadın tüketicilerin dış görünümde markalı ürün kullanma bilincinin gösterişçi tüketim üzerindeki etkisinin; marka duygusu seviyesi ortalamanın bir standart sapma üstünde (+1 doğrusu), ortalama (0 doğrusu) ve ortalamanın bir standart sapma altında ( -1 Doğrusu) olan doğruların $\beta$ değerlerinin (sırayla $0,39,0,40$ ve 0,041) arasında istatistiksel olarak anlamlı bir fark olmadığı (Tablo 6: $\beta=-0,008$ ve p değeri 0,882 >0,05) görülmektedir. Diğer taraftan erkek tüketicilerin dış görünümde markalı ürün kullanma bilincinin gösterişçi tüketim üzerindeki etkisinin; marka duygusu seviyesi, ortalamanın bir standart sapma üstünde (+1 doğrusu), ortalama (0 doğrusu) ve ortalamanın bir standart sapma altında (-1 doğrusu) olan doğruların $\beta$ değerlerinin (sırayla $0,69,0,53$ ve 0,36$)$ arasında istatistiksel olarak anlamlı bir fark olduğu (Tablo 6 : $\beta=0,13$ ve p değeri $0,000<0,05$ ) görülmektedir. Tablo 6, Tablo 7 ve Grafik 2 'den elde edilen sonuçlara dayanarak, tüketicilerin dış görünümde markalı ürün kullanma bilinci ile gösterişçi tüketim arasındaki ilişkide marka duygusunun düzenleyici etkisi cinsiyete göre değişmektedir şeklindeki Hipotez 3 kabul edilmiştir.

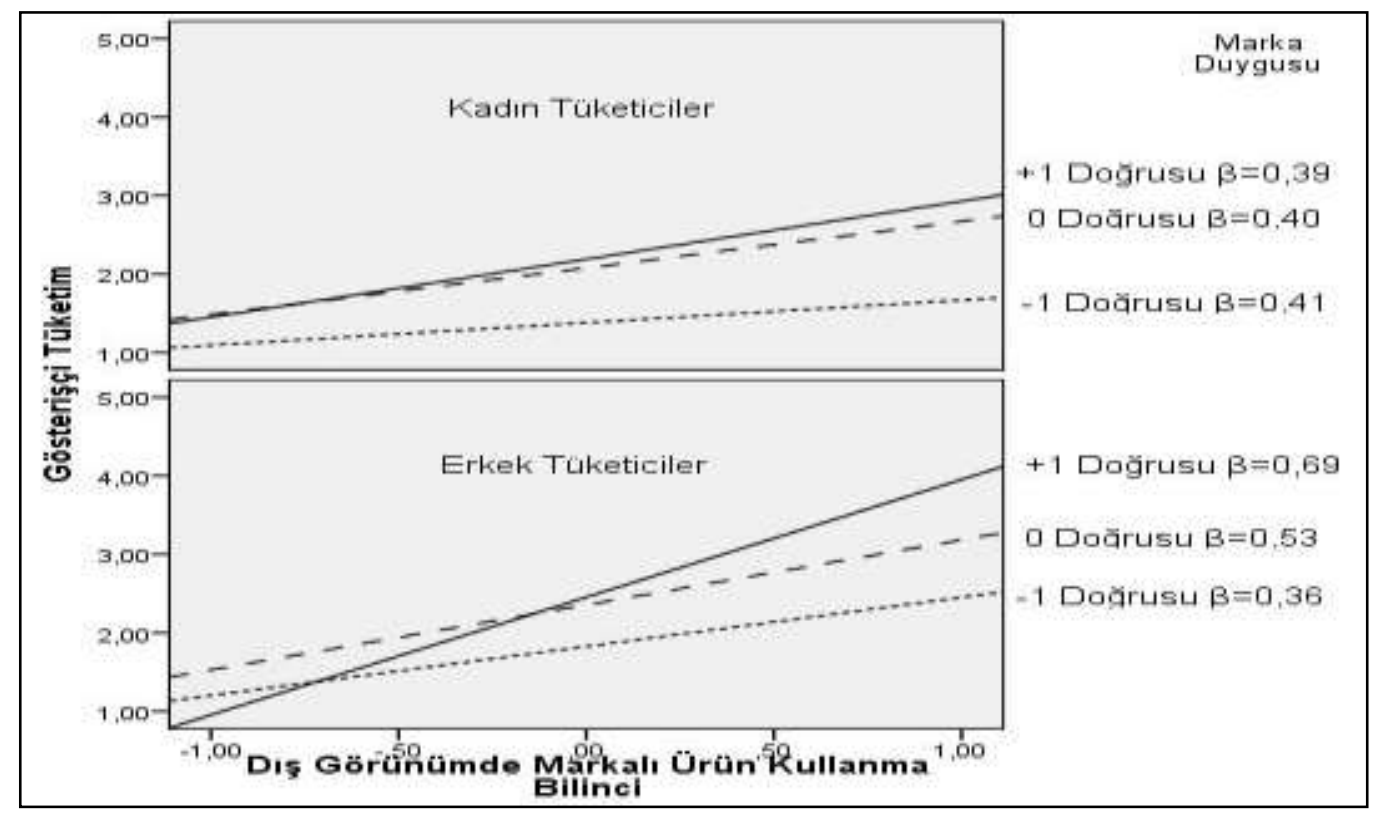

Grafik 2. Dış Görünümde Markalı Ürün Kullanma Bilincinin Gösterişçi Tüketim Üzerindeki Etkisinin Cinsiyet Açısından Marka Duygusunun Durumsal Eğim Grafiği

\section{Sonuç}

Araştırmanın ilk sorusu, dış görünümde markalı ürün kullanma bilincinin gösterişçi tüketim üzerinde etkisini incelemekti. Analizler sonucunda elde edilen bulgulardan da anlaşılabileceği gibi, dış görünümde markalı ürün kullanma bilincinin gösterişçi tüketim üzerinde olumlu yönde etkisi olduğu (Tablo 4, Şekil 1a) anlaşılmıştır. Bu sonuç literatürde Li ve Su (2007), Li vd. (2018), Zhang ve Wang (2019) gibi çalışmaları destekler niteliktedir. Buradan hareketle, markalı ürünlerin 
olumlu dışsal görünümlerinin kendi dış görünümlerini de olumlu yönde etkileyeceğini düşünen tüketicilerin gösterişçi tüketim yapacağı sonucuna ulaşıldığı söylenebilir.

Araştırmanın ikinci sorusu, dış görünümde markalı ürün kullanma bilincinin gösterişçi tüketim üzerindeki etkisi, marka duygusu seviyesi yüksek olan tüketicilerde güçlü olup olmadığını incelemekti. Dış görünümde markalı ürün kullanma bilincinin gösterişçi tüketim üzerindeki etkisinin, marka duygusu seviyesi yükseldikçe güçlendiği (Tablo 4, Şekil 1b, Grafik 1) anlaşılmıştır. Bu sonuç, literatürde Chaudhuri, ve Holbrook'un (2001 ve 2002) çalışmalarında, ürün sınıfının marka çıktıları üzerinde etkisinin marka duygusuyla düzenlendiği; Mazodier ve Merunka'nın (2012) sponsorluk faaliyetlerinin marka bağlılı̆̆ı elde etmede marka duygusunun aracılık etkisi gösterdiği gibi çalışmaları destekler niteliktedir. Dolayısıyla, markalı ürün kullanma sonucunda elde edilen olumlu duygusal etkinin (mutlu, iyi ve keyifli hissetmek gibi) yükselmesi, tüketicinin, dış görünümüne önem verme bilincini de olumlu yönde etkilediği ve sonuçta gösterişçi tüketim yaptıkları anlaşılmıştır.

Araştırmanın üçüncü sorusu, dış görünümde markalı ürün kullanma bilincinin gösterişçi tüketim üzerindeki etkisinin, marka duygusu seviyesi yüksek olan kadın ve erkekler arasında fark olup olmadığını incelemekti. Analizler sonucunda elde edilen bulgulardan da anlaşılabileceği gibi dış görünümde markalı ürün kullanma bilincinin gösterişçi tüketim üzerindeki etkisi, erkek tüketicilerin marka duygusu seviyeleri arasında anlamlı şekilde değiştiği (Tablo 4, Şekil 1c, Grafik 2) anlaşılmıştır. Diğer taraftan kadın tüketicilerde, marka duygusu seviyesi düşük, orta veya yüksek olanlar arasında, dış görünümde markalı ürün kullanma bilincinin gösterişçi tüketim üzerindeki etkisinin anlamlı şekilde değişmediği (Tablo 4, Şekil 1c, Grafik 2) anlaşılmıştır. Başka bir ifadeyle, dış görünümde markalı ürün kullanma bilincinin gösterişçi tüketim üzerindeki etkisinin, marka duygusu etkileşiminin erkek tüketiciler açısından durumsal düzenleyici etkisi (Tablo $6, \beta=$ $0,13, p=0,000$ ) olduğu, ancak kadınlar için durumsal düzenleyici etkisinin (Tablo $6, \beta=-0,008, p=0,882$ ) bulunmadı̆̆ anlaşılmıştır. Bu sonuç, literatürde Melnyk ve diğerlerinin (2009) kadınların markalara nitelik açısından yaklaştığı, erkeklerin ise markalara duygusal nedenlerle (mutlu, iyi ve keyifli hissetmek) yaklaştı̆̆ 1 araştırmasını destekler niteliktedir. Diğer taraftan, Wong ve Ahuvia (1998), Sahay vd., (2012), Tokgöz (2019) ve Li ve diğerlerinin (2015) ileri sürdükleri toplumsal ve bireysel tüketim kültürü farklılıklarının cinsiyet açısından değiştiği şeklindeki araştırmaları destekler niteliktedir.

Elde edilen sonuçlarla, markalı ürün pazarında faaliyet gösteren pazarlamacılar, üç farklı tutundurma yönetimi stratejisi belirleyebilir. İlk strateji, dış görünümde markalı ürün kullanıp gösterişçi tüketim yapanları, "markalı ürünlerle sosyal ortamlara uyum sağlayanlar" sloganıyla ilişskilendirebilirler. Elde edilen bu sonuç markalar açısından incelendiğinde, pazarlama iletişimi (tutundurma faaliyetleri) yönetimi için stratejik bir ilke olarak düşünülebilir. Bu nedenle özellikle pazarlama yöneticileri markalı ürünlerini arz ederken, tüketicilere, ürünlerin kullanıcılarını sosyal ortamlarda etkileşimlerinde rahatlık sağlayacağını içeren pazarlama iletişimi araçlarıyla ulaşmaları yararlı olabilir.

İkinci stratejik ilke, marka duygusu seviyesi yüksek olduğu için mutluluğu, iyi olmayı ve keyifli hissetmeyi yakalama düşüncesiyle dış görünüşlerinde markalı ürün kullanma bilinciyle gösterişçi tüketim yapanları, "mutlu olmak için dış görünümleriyle gösteriş yapanlar" sloganıyla ilişkilendirebilirler. Elde edilen bu sonuç işletmeler açısından incelendiğinde, marka yöneticilerinin pazarlama iletişimi faaliyetleri için stratejik bir ilke olarak düşünülmesinde faydalı olabilir. Bu nedenle özellikle pazarlama yöneticileri markalı ürünlerini arz ederken, tüketicilere (cinsiyet ayırmadan), marka duygusunun düzenleyici etkisinden yararlanarak, markalı ürünlerini kullananların mutlu olacaklarını ve keyifli hissedeceklerini anlatan içeriğe sahip pazarlama iletişimi araçlarıyla ulaşmaları yararlı olabilir. Bu stratejik ilke, cinsiyet ayırmaksızın, tüm hedef tüketiciler için kullanılabilir.

Üçüncü stratejik ilke, marka duygusu seviyesi yüksek olduğu için dış görünümünde markalı ürün kullanma bilinciyle hareket edip gösterişçi tüketim yapan erkekleri, "diğer erkeklerin markalı ürünleri satın alarak mutlu olduğunu gördüğü için satın alan erkekler” sloganıyla ilişkilendirebilirler. Elde edilen bu sonuç işletmeler açısından incelendiğinde, marka yöneticilerinin pazarlama iletişimi faaliyetleri için stratejik bir ilke olarak düşünülmesinde faydalı olabilir. Buna göre, marka yöneticileri ürünlerini arz ederken, özellikle erkek tüketiciler için, marka duygusunun düzenleyici etkisinden yararlanarak, bu ürünleri kullanan diğer erkeklerin mutlu olduklarını ve keyifli hissettiklerini anlatan içeriğe sahip pazarlama iletişimi araçlarıyla ulaşmaları yararlı olabilir. Bu stratejik ilke, sadece erkek ürünlerini kullanan erkek tüketiciler hedef alınarak kullanılabilir.

Teorik bölümde ifade edildiği gibi marka üzerine yapılan araştırmalardan bazıları, tüketimde kültür farklılıklarını ortaya koymaktadır (Oetzel ve Ting-Toomey, 2003; Li ve Su, 2007; Vohra, 2016; Li vd., 2018; Tokgöz, 2019; Zhang ve Wang, 2019). Bu çalışmada, kültürel unsurların marka üzerindeki etkisi araştırılmamışsa da, elde edilen sonuçların önceki çalışmaları destekler nitelikte olduğu görülmektedir. Gelecekte markaya ilişkin tüketici davranışlarıyla ilgili yapılacak araştırmalarda kültür farklılıklarını ortaya koyabilecek farklı değişkenler üzerinde araştırma yapılması yararlı olabilir.

Çalışma kapsamında, değişkenler için oluşturulan anket formunda herhangi bir marka veya sektörün işaret edilmemesi kısıtlardan birisidir. İleride yapılacak araştırmaların, farklı markalar veya sektörler işaret edilerek yapılması konunun genelleşmesine yardımcı olacaktır. Örneklem olarak sadece üniversitede okuyan, yakın yaş grubundaki öğrencilerin seçilmesi de başka bir kısıttır. Diğer taraftan çalışmanın sadece belirli bir bölgede yapılması, farklı kültürel özelliklere sahip bölgelerde veya farklı yaş gruplarıyla karşılaştırma yapılamaması diğer kısıtlar olarak sıralanabilir. Söz edilen kısıtlar nedeniyle, çalışmanın sonuçlarını tüm tüketicilere, bölgeye veya ülkeye genellemek mümkün olmayabilir. 
Tokgöz, E. / Journal of Yasar University, 2020, 15/59, 584-597

\section{KAYNAKÇA}

Afif, Nur Choirul, Sutiksno, Dian Utami, Hardiyanto, Nugroho ve Shiratina, Aldina 2015. "Building Brand Loyalty Through Increasing Brand Trust And Brand Affect". International Journal of Scientific \& Technology Research, 4, 11: 336-340.

Assimos, Bruno Medeiros, Pinto, Marcelo de Rezende, Leite, Ramon Silva ve Andrade, Matheus Lemos de 2019. "Conspicuous Consumption and its Relation to Brand Consciousness, Status Consumption and Self-Expression". Brazilian Business Review, 350-368. DOI: http://dx.doi.org/10.15728/bbr.2019.16.4.3

Aziz, A. 2008. Sosyal Bilimlerde Araştırma Yöntemleri ve Teknikleri. Ankara: Nobel Yayın Dağıtım.

Aziz, Muhammad Asim ve Habib, Muhammad Danish 2017. "Effects of Social Value, Self-Discrepancy, and Face Consciousness on Status Consumption: Perceived Consumer Need for Uniqueness as a Mediator". Journal of Business Studies Quarterly, 8, 4: 61-75.

Balıkçıŏlu, Betül ve Volkan, Pelin 2016. "Sosyal Medya, Televizyon ve Akran İletişiminin Materyalizm ve Gösteriş Tüketimi Üzerindeki Etkisi: Tüketici Sosyalleşmesi Perspektifi”. Mustafa Kemal Üniversitesi Sosyal Bilimler Enstitüsü Dergisi, 13, 35: 299-319.

Bayuk, M. Nedim ve Öz, Abdullah 2018. "Sosyal Medya Ortamında Gösterişçi Tüketimin Sergilenmesi”. Journal of Social and Humanities Sciences Research, 5, 27: 2846-2861.

Bao, Yeqing, Zhou, Kevin Zheng ve Su, Chenting 2003. "Face Consciousness and Risk Aversion: Do They Affect Consumer Decision-Making?". Psychology \& Marketing, 20: 733-755.

Becan, Cihan ve Eaghanıoskouı, Ghoncheh 2019. "Gösterişçi Tüketim Aracı Olarak Instagramın Tüketicilerin Satın Alma Motivasyonuna Etkisi”. Yeni Medya Elektronik Dergi, 3, 2: 84-101.

Belk, Russel W. 1988. "Possessions and the Extended Self.". Journal of Consumer Research, 15: 139-168.

Berger, Jonah ve Ward, Morgan 2010. "Subtle Signals of Inconspicuous Consumption.” Journal of Consumer Research, 37, 4: 555-569. http://dx.doi.org/10.1086/655445

Burmaoğlu, Serhat, Polat, Mustafa ve Meydan, Cem Harun 2013. “Örgütsel Davranış Alanında İlişkisel Analiz Yöntemleri ve Türkçe Yazında Aracılık Modeli Kullanımı Üzerine Bir İnceleme”. Anadolu Üniversitesi Sosyal Bilimler Dergisi, 13, 1: 13-26.

Büyüköztürk, Ş., E. K. Çakmak, Ö. E. Akgün, Ş. Karadeniz ve F. Demirel 2009. Bilimsel Araştırma Yöntemleri. Ankara, Pegem Akademi.

Chaudhuri, Arjun ve Holbrook, Morris B. 2001. "The Chain of Effects from Brand Trust and Brand Affect to Brand Performance: The Role of Brand Loyalty". Journal of Marketing, 65, 2: 81-93.

Chaudhuri, Arjun ve Holbrook, Morris B. 2002. "Product-Class Effects on Brand Commitment and Brand Outcomes: The Role of Brand Trust and Brand Affect". Journal of Brand Management, 10, 1: 33-58.

Chaudhuri, Himadri Roy, Mazumdar, S. ve Ghoshal, A. 2011. "Conspicuous Consumption Orientation: Conceptualisation, Scale Development and Validation”. Journal of Consumer Behaviour, 10: 216-224.

Chen, Yun Qing, Zhu, Hong, Le, Meng ve Wu, Yi-Zhen 2014. "The Effect of Face Consciousness on Consumption of Counterfeit Luxury Goods". Social Behavior and Personality, 42, 6: 1007-1014.

Chen, Si, Shao, Bingjia ve Zhi, Kuiyun 2018. "Predictors of Chinese Users' Location Disclosure Behavior: An Empirical Study on WeChat". Information 9, 219: 1-13.

Dal, Nil Esra, Korkmaz, İlknur ve Yalçın, Mustafa 2018. “Sosyal Uyum Ve Materyalizm Etkisinde Gösteriş Tüketimine Bir Bakış". International Journal of Economic and Administrative Studies, 17: 69-84.

Diamantopoulos, Adamantios ve Siguaw, Judy A. 2000. Introducing LISREL A Guide for The Uninitiated, London, Sage Publication.

Dick, Alan S. ve Basu, Kunal 1994. "Customer loyalty: Toward an Integrated Conceptual Framework”. Journal of the Academy of Marketing Science, 22, 2: 99-113. http://dx.doi.org/10.1177/0092070394222001

Eroğlu, Filiz 2016. "Kompulsif Satın Alma: Kişisel Faktörler, Postmodern Tüketim Şekilleri ve Reklama Karşı Tutumun Rolüne Yönelik Bir Araştırma”. Balıkesir Üniversitesi Sosyal Bilimler Enstitüsü Dergisi, 19, 35: 253-282.

Fornell, Claes ve Larcker, David F. 1981. "Evaluating Structural Equation Models with Unobservable Variables and Measurement Error". Journal of Marketing Research, 18: 39-50.

Geçti, Fatih ve Zengin, Hayrettin 2013. "The Relationship between Brand Trust, Brand Affect, Attitudinal Loyalty and Behavioral Loyalty: A Field Study towards Sports Shoe Consumers in Turkey". International Journal of Marketing Studies, 5, 2: 111-119.

Gao, Ge 1998. "An Initial Analysis of the Effects of Face and Concern for "Other" in Chinese Interpersonal Communication”. International Journal of Intercultural Relation, 22: 467-482.

Goldsmith, Ronald E., Flynn, Leisa Reinecke ve Eastman, Jacqueline K. 1996. "Status Consumption and Fashion Behavior: An Exploratory Study". Association of Marketing Theory and Practice, Spring: 309-315.

Grainger, Karen, Mills, Sara ve Sibanda, Mandla 2010. ““'Just Tell Us What to Do": Southern African Face and its Relevance to Intercultural Communication”. Journal of Pragmatics, 42: 2158-2171.

Hair, Joseph F., Black, William C., Babin, Barry J. ve Anderson, Rolph E. 2010. Multivariate Data Analysis, (7. Edition), New Jersey.

Hayes, A.F. 2013. PROCESS for SPSS 2.16.3. http://www.guilford.com/p/hayes3, İnternet Erişim Tarihi: 24.03.2018. 
Hayes, Andrew F., Montoyai Amanda K. ve Rockwood, Nicholas J. 2017. "The Analysis of Mechanisms and their Contingencies: PROCESS versus Structural Eqation Modeling”. Austrilian Marketing Journal, 25: 76-81.

Hayes, Andrew F. 2018. Introduction to Mediation, Moderation, and Conditional Process Analysis: A Regression-Based Approach. Second Edition, New York, The Guilford Press.

Jiang, Ling ve Shan, Juan 2016. "Counterfeits or Shanzhai? The Role of Face and Brand Consciousness in Luxury Copycat Consumption”. Psychological Reports, 119, 1: 181-199.

Kabaday1, Ebru Tümer ve Alan, Alev Koçak 2012. "Brand Trust And Brand Affect: Theır Strategıc Importance On Brand Loyalty". Journal of Global Strategic Management, 6, 1: 80-88.

Kozak, M. 2015. Bilimsel Araştırma: Tasarım, Yazım ve Yayım Teknikleri. Ankara, Detay Yayıncılık.

Laurencelle, L. ve Dupuis F.A. 2002. Statistical Tables, Explained and Applied. River Edge, SG: World Scientific Publishing.

Liao, Jiangqun ve Wang, Lei 2009. "Face as a Mediator of the Relationship between Material Value and Brand Consciousness". Psychology \& Marketing, 26, 11: 987-1001.

Li, Jie, Zhang, Xing-An. ve Sun, Gong 2015. "Effects Of Face Consciousness On Status Consumption Among Chinese Consumers: Perceived Social Value As a Mediator". Psychological Reports: Sociocultural Issues in Psychology, 116, 1: 1-12.

Li, Julie Juan ve Su, Chenting 2007. "How face influences consumption A comparative study of American and Chinese consumers". International Journal of Market Research, 49, 2: 237-256.

Li, Rui, Xu, Jia, Zhou, Mingshan ve Wang, Tianyu 2018. "Advance or face Which Makes Chinese Entrepreneurial Households Spend More on Education?”. Chinese Management Studies, 12, 3: 620-633.

Lee, Seung-Hee, Workman, Jane ve Jung, Kwangho 2017. "Face Consciousness, Gender, and Money Attitudes". International Textile and Apparel Association (ITAA) Annual Conference Proceedings, 1-2.

Matzler, Kurt, Bidmon, Sonja ve Krauter, Sonja Grabner-Krauter 2006. "Individual Determinants of Brand Affect: The Role of The Personality Traits of Extraversion and Openness to Experience". Journal of Product \& Brand Management, 15, 7: 427-434.

Mazodier, Mare ve Merunka, Dwight 2012. “Achieving Brand Loyalty Through Sponsorship: The Role Of Fit And SelfCongruity”. Journal of the Academy Marketing Science, 40: 807-820.

Melnyk, Valentyna, van Osselaer, Stijn M., ve Bijmolt, Tammo H.A. 2009. “Are Women More Loyal Customers than Men? Gender Differences in Loyalty to Firms and Individual Service Providers". Journal of Marketing, 73: 8296.

Nakip, M. 2013. Pazarlamada Araştırma Teknikleri ve SPSS Uygulamaları. Ankara, Seçkin Yayıncılık.

O’Cass, Aron ve McEwen, Hmily 2004. "Exploring Consumer Status and Conspicuous Consumption”. Journal of Consumer Behaviour, 4, 1: 25-39.

Oetzel, John G. ve Ting-Toomey, Stella 2003. "Face Concerns in Interpersonal Conflict A Cross-Cultural Empirical Test of the Face Negotiation Theory". Communication Research, 30, 6: 599-624.

Podoshen, Jeffrey S. ve Andrzejewski, Susan A. 2012. "An Examination of the Relationships Between Materialism, Conspicuous Consumption, Impulse Buying, and Brand Loyalty". Journal of Marketing Theory and Practice, 20, 3: 319-333.

Sahay, Arvind, Sharma, Nivedita ve Mehta, Krishnesh 2012. "Role of Affect and Cognition in Consumer Brand Relationship: Exploring Gender Differences". Journal of Indian Business Research, 4, 1: 36-60.

Souiden, Nizar, M’Saad, Bouthaina ve Pons, Frank 2011. “A Cross-Cultural Analysis of Consumers' Conspicuous Consumption of Branded Fashion Accessories”. Journal of International Consumer Marketing, 23: 329-343.

Şahin, Onur ve Nasır, Süphan 2019. “Tüketicilerin Gösterişçi Tüketime Yönelik Tutumlarına Göre Sınıflandırılması”. Balıkesir Üniversitesi Sosyal Bilimler Enstitüsü Dergisi, 22, 41: 383-399.

Şeşen, Elif ve Şıker, Perihan 2019. "Kahvehaneden Starbucks'a: Gösterişçi Tüketimden Gösterişçi Sıradanlığa”. Social Sciences Studies Journal, 5, 38: 3345-3356.

Truong, Yann, Simmons, Geoff, McColl, Rodd ve Kitchen, Philip J. 2008. "Status and Conspicuousness-Are They Related? Strategic Marketing Implications for Luxury Brands”. Journal of Strategic Marketing, 16, 3: 189-203.

Tokmak, Gizem 2019. "Materyalist Eğilim ve Tüketici Ahlakının Gösterişçi Tüketim Eğilimi Üzerindeki Etkisi”. IBAD Sosyal Bilimler Dergisi, 5: 359-378.

Tokgöz, Emrah 2019. “Genç Tüketicilerin Kişilerarası Etkiye Duyarlılığının Analizi: Demografik Değişkenler ve Markalı Ürün Grupları Açısından İnceleme". II. International Conference on Empirical Economics and Social Sciences (ICEESS'19), Bandirma, Turkey: 290-308.

Türk Dil Kurumu, Büyük Sözlük, 10.10.2019 http://tdk.gov.tr/, İnternet Erişimi.

Veblen, Thorstein 1899. The theory of the leisure class. New York, Vanguard Press.

Vohra, Aastha Verma 2016. "Materialism, Impulse Buying and Conspicuous Consumption: A Qualitative Research". Global Business Review, 17, 1: 51-67.

Wong, Nancy Y. ve Ahuvia, Aaron C. 1998. "Personal Taste and Family Face: Luxury Consumption in Confucian and Western Societies". Psychology and Marketing, 15: 423-441.

Zhang, Xin-an ve Wang, Wangshuai 2019. "Face consciousness and Conspicuous Luxury Consumption in China". Journal of Contemporary Marketing Science, https://doi.org/10.1108/ JCMARS-01-2019-0002. 